\title{
Detection of tuberculosis: respiratory symptoms flow and results achieved
}

\author{
Detecção da tuberculose: fluxo dos sintomáticos respiratórios e resultados alcançados \\ Detección de la tuberculosis: flujo de los sintomáticos respiratorios y resultados alcanzados
}

\begin{abstract}
Lílian Moura de Lima Spagnolo', Jéssica Oliveira Tomberg',
Dagoberta Alves Vieira', Roxana Isabel Cardozo Gonzales'
' Universidade Federal de Pelotas, Nursing School. Pelotas, Rio Grande do Sul, Brazil.
How to cite this article:
$\begin{gathered}\text { Spagnolo LML, Tomberg JO, Vieira DA, Gonzales RIC. Detection of tuberculosis: respiratory symptoms flow and results } \\ \text { achieved. Rev Bras Enferm [Internet]. 2018;71(5):2543-51. DOI: http://dx.doi.org/ 10.1590/0034-7167-2017-0457 }\end{gathered}$
\end{abstract}
Submission: 06-21-2017 Approval: 02-07-2018

\begin{abstract}
Objective: to analyze the flow of care to the person with symptoms of tuberculosis and the results achieved in the detection of cases in Primary Health Care units of two municipalities of Rio Grande do Sul. Method: descriptive of mixed methods, developed between 2013 and 2016. We used secondary data of 69 units and semi-structured interviews with 10 professionals. Descriptive statistical analysis and content analysis were used. Results: it was observed that the fragmented flow of attention to the respiratory symptoms in Pelotas resulted in low detection of cases by Primary Care, $8.8 \%$ of the diagnoses of the municipality. The Sapucaia do Sul flow presents continuity of care, and Primary Care performed $50 \%$ of the diagnoses of the municipality. Conclusion: the organization of flows by municipal management was instrumental in promoting or limiting the commitment of Primary Health Care teams in coordinating care and consequently in achieving the goals of disease control.

Descriptors: Research on Health Services; Primary Health Care; Tuberculosis; Primary Prevention; Public Health.
\end{abstract}

\section{RESUMO}

Objetivo: analisar o fluxo de atenção à pessoa com sintomas de tuberculose e os resultados alcançados na detecção de casos, em unidades de Atenção Primária à Saúde de dois municípios do Rio Grande do Sul. Método: descritivo de métodos mistos, desenvolvido entre 2013 e 2016. Utilizando dados secundários de 69 unidades e entrevistas semiestruturadas com 10 profissionais. Foram empregadas a análise estatística descritiva e a análise de conteúdo. Resultados: observou-se que o fluxo fragmentado de atenção ao sintomático respiratório, em Pelotas, resultou em baixa detecção de casos pela Atenção Primária, 8,8\% dos diagnósticos do município. O fluxo de Sapucaia do Sul apresenta continuidade da assistência, e a Atenção Primária realizou 50\% dos diagnósticos do município. Conclusão: a organização dos fluxos, pela gestão municipal, foi determinante para promover ou limitar o comprometimento das equipes da Atenção Primária à Saúde na coordenação da assistência, e consequentemente no alcance das metas de controle da doença.

Descritores: Pesquisa sobre Serviços de Saúde; Atenção Primária à Saúde; Tuberculose; Prevenção Primária; Saúde Pública.

\section{RESUMEN}

Objetivo: analizar el flujo de atención a la persona con síntomas de tuberculosis y los resultados alcanzados en la detección de casos en unidades de Atención Primaria a la Salud de dos municipios de Rio Grande do Sul. Método: descriptivo de métodos mixtos, desarrollado entre 2013 y 2016. Utilizando datos secundarios de 69 unidades y entrevistas semiestructuradas con 10 profesionales. Se utilizaron el análisis estadístico descriptivo y el análisis de contenido. Resultados: se observó que el flujo fragmentado de atención al sintomático respiratorio, en Pelotas, resultó en baja detección de casos por la Atención Primaria, el $8,8 \%$ de los diagnósticos del municipio. El flujo de Sapucaia del Sur presenta continuidad de la asistencia, y la Atención Primaria realizó el 50\% de los diagnósticos del municipio. Conclusión: la organización de los flujos, por la gestión municipal, fue determinante para promover o limitar el compromiso de los equipos de la Atención Primaria a la Salud en la coordinación de la asistencia, y consecuentemente en el logro de las metas de control de la enfermedad.

Descriptores: Investigación sobre Servicios de Salud; Atención Primaria a la Salud; Tuberculosis; Prevención Primaria; Salud Pública. 


\section{INTRODUCTION}

Tuberculosis (TB) remains a major public health problem worldwide, especially in developing countries. Brazil is listed among the 30 countries that concentrate $83 \%$ of the world's tuberculosis cases ${ }^{(1)}$. The national incidence in 2016 was 32.4/100 thousand inhabitants, and in the state of Rio Grande do Sul it was higher, with 37.5/100 thousand inhabitants ${ }^{(2)}$.

The main strategy for the control of TB is the early detection of bacilliferous pulmonary cases, due to its epidemiological importance in the maintenance of transmission; followed by the appropriate treatment and extent of cure ${ }^{(3)}$. Between 2000 and 2014, 43 million people were killed by early diagnosis and treatment of the disease ${ }^{(1)}$. Considering the importance of these actions, the World Health Organization $(\mathrm{WHO})$ has determined that in order to achieve effective TB control, $70 \%$ of the estimated cases should be detected for a given period and at least $85 \%$ of those diagnosed should be cured ${ }^{(2)}$.

In view of the consensus on the profile of those affected by TB, priority should be given to individuals with social vulnerability ${ }^{(3)}$, the need to guarantee access to and follow-up of these by the Brazilian Unified Health System (Sistema Único de Saúde-SUS) is recognized. Since, one of the factors determining the access of the users is the distance from the service to the home ${ }^{(4)}$, in this sense, Primary Health Care (PHC) appears as the ideal entry point for Tuberculosis Respiratory Symptoms (RS) people with cough for three weeks or more ${ }^{(5)}$.

There is still a need for agility and resilience of multidisciplinary teams motivated and committed to TB control, which act extensively in the active search for cases in the community, supported by municipal management with the organization of standardized flows, and adequate information systems for the safe RS by the care network necessary for case detection and treatment ${ }^{(6-7)}$.

However, in spite of the simplicity of sputum smear examination, for the detection of cases, there are still difficulties in speeding up the early diagnosis of $\mathrm{TB}^{(8)}$, evidenced in studies carried out in Brazil, which point to the incipient contribution of $\mathrm{PHC}$ in the early detection of cases of TB. The authors point out aspects related to the delay in diagnosis by RS, to perceive patients and to seek health care, as well as limitations related to PHC, including barriers in access and failures related to the low resolution and fragmentation of care with referrals to services specialized ${ }^{(4,9-10)}$.

For the reasons explained, this study aims to analyze the flow of attention to the person with symptoms of tuberculosis and the results achieved in the detection of cases in Primary Health Care units of two municipalities of Rio Grande do Sul State.

\section{OBJECTIVE}

To analyze the flow of attention to the person with symptoms of tuberculosis and the results achieved in the detection of cases in Primary Health Care units of two municipalities of Rio Grande do Sul.

\section{METHOD}

\section{Ethical aspects}

In carrying out this study, the ethical precepts of the Declaration of Helsinki and Resolution 466/12 of the Brazilian National
Health Council (Conselho Nacional de Saúde- CNS)(11) were respected, the Informed Consent Form was given in data collection, and the anonymity of the interviewees was guaranteed using letters are identified for their identification, the letter $M$ being in the case of management representatives and the letter $\mathrm{P}$ for professionals, accompanied by the initial letter of the municipality. The project was submitted to the Brazil Platform in its quantitative stage with favorable appreciation. The qualitative stage submitted subsequently received a favorable opinion.

\section{Design, place of study and period}

This is an evaluative study of mixed methods, sequential explanatory type. It was developed between 2013 and 2016, with an analysis of actions to detect TB cases from PHC in Pelotas and Sapucaia do Sul. The municipalities were selected for being part of the list of priority municipalities for TB control in Rio Grande do Sul, besides having municipalization of the Tuberculosis Control Program ${ }^{(12)}$.

\section{Population and criteria for inclusion and exclusion}

The study was divided into two stages, the first quantitative, originated from a multicenter ${ }^{(13)}$ census survey, conducted between October 2013 and November 2014, in which data were collected on visits to the $69 \mathrm{PHC}$ units of the municipalities under study. The second qualitative phase, conducted in 2016, with the application of semi-structured interviews to the municipal managers responsible for TB control actions, and $\mathrm{PHC}$ professionals responsible for these actions in their work units. Service time greater than six months was used as inclusion criterion.

\section{Quantitative study protocol}

For the quantitative collection of data, a structured and previously coded form was used, constructed by the authors of the original research, having as source of data the Logbooks of Respiratory Symptoms of PHC (LBRS), Logbook of Sputum Smears of Laboratories (LBL) and Case Follow-up Book (CFB) in the units where the treatments are performed, data for the year 2012. In the LBRS the dates of the smear examination request were collected by the PHC; in the LBL was collected the date of the examination and the respective result. In the CFB of the treatment units, the starting date of the treatment unit.

\section{Analysis of quantitative results and statistics}

The analysis of these variables allowed to calculate the indicators of proportion of RS identified among the estimated ( $1 \%$ of the total population), as well as the proportion of diagnoses among those examined (Number of RS examined/Number of cases identified), the expected percentage would be of $4 \%{ }^{6}$. The time elapsed between each stage, from the discovery of RS in the territory until the beginning of the treatment (request of the PHC examination - entry of the sample in the laboratory, release of the result-beginning of the treatment) was calculated and the proportion of diagnoses by $\mathrm{PHC}$ in relation to the total number of diagnoses in the municipality (data from the SINAN). The data collected were entered with a double entry in a database built in the Exce ${ }^{\circledR}$ program, and the information was consistently tested 
and then converted to Statsoft ${ }^{\circledR}$ Statistical Program 12 format, with which the analysis was performed statistics, describing the relative and absolute frequencies of the variables.

\section{Qualitative data source}

For the qualitative collection with the health professionals, a stratification of the PHC units of the municipalities was carried out, starting from the verification of the number of records of smear de sputum requests for the year 2012, collected in the quantitative stage. Thus, health services were categorized by the lowest, middle and highest number of requests. In Sapucaia do Sul the three groups ( 3 to 36 requests - 11 units, 37 to 73 requests - six units, 74 to 111 requests - two units). For Pelotas, in addition to these categories, two more were created, due to the absence of a logbook in all the units, and others did not have request records (without a logbook - 24 units, with book and without requests - seven units, one to nine requests - 11 units, ten to 18 requests - six units, and 19 to 27 requests - two units).

From this stratification, a unit was drawn in each category, totaling eight units, to make the telephone contact, and scheduling the interview with the professional responsible for TB. The group of units drawn in Pelotas was composed of two Traditional Basic Health Units (TBHS) and three units of Family Health Strategy (FHS). In Sapucaia do Sul, the group was composed of a TBHS, a FHS and a unit in transition from TBHS to FHS. In all units, the professional who identified himself as responsible for the actions was the Nurse. The criterion of inclusion was the service time equal to or greater than six months in the PHC of the municipality.

Regarding the interviews with the municipal managers responsible for TB control actions in Pelotas, the interviewed professional was the Director of the health actions of Primary Care, and in Sapucaia do Sul he was the Coordinator of municipal epidemiological surveillance.

\section{Collection and organization of qualitative data}

The semi-structured interviews were composed of open questions about the organization of $\mathrm{PHC}$ to attend $\mathrm{TB}$, about the actions developed in the $\mathrm{PHC}$ to detect cases, and about the professional's perception about the potentialities and fragilities of the municipal organization for the control of TB. The interviews were recorded in audio and later transcribed.

\section{Analysis of qualitative data}

The analysis was performed by Hyper Research ${ }^{\circledR}$ software version 2.8.3, using content analysis, thematic modality ${ }^{(14)}$, seeking to identify the presence of themes that composed the interviews and interpret their meanings. From the analysis emerged the themes of structure and flows of attention. For the purpose of this publication, the topic of care flow will be addressed, which allowed the construction of the case detection flowcharts of each municipality.

\section{RESUITS}

Pelotas is located in the southern region of the state, has a population of 343,651 inhabitants and is organized in six health districts with 50 units of PHC, with coverage of the Family Health Strategy (FHS) of $70.2 \%$ of the population in June 2016. Case detection is decentralized to PHC and treatment is centralized in a single outpatient service. Sapucaia do Sul, located in the metropolitan region of Porto Alegre, has a population of 138,933 inhabitants, is organized in four health districts, with 19 PHC units, with FHS coverage of $49.6 \%$ of the population in June 2016. In which the actions of TB control are municipalized and decentralized to $\mathrm{PHC}^{(15-16)}$.

From the qualitative interviews with the PHC's municipal and professional managers, it was possible to construct the flowchart of the disease detection actions, as shown below. Figure 1 shows the Pelotas flow, which has the decentralized detection actions for PHC, a municipal laboratory for smear s, and centralized treatment in an outpatient service, with monthly dispensing of medications for self-administered treatment.

Figure 2 shows the Sapucaia do Sul case detection flow, which has the directly observed detection and treatment actions, decentralized to the PHC. The Municipality counts on a laboratory for the smear exams of sputum.

According to the interviewees, there is no documented flow, but verbal orientations about the conduction of RS in the network.

There is nothing like that on paper, but the orientation we always had was this flow, we would send it to the center of specialties, or we would also make the request for an exam and then go to the laboratory and be handled at the specialty center that was what I knew. (P3-P)

There is not on paper. But it has always been done so [referring to the patient's referral flow], everyone knows how to carry out independently of the unit. And in case of doubt if it makes the direct contact with the TB, it works very well! (P2-S)

Regarding the continuity of care in the municipal case-finding flow (Figure 1), and the PHC's responsibility in conducting RS until diagnosis and cure, Pelotas professionals reported the fragmentation of care. And they link this occurrence to the centralization of the treatment, which for them strengthens the culture of disclaiming the PHC by monitoring the cases, leaving PHC with the task of offering the bottles and ordering.

For me this organization does not guarantee! And centralization is a fragility, as far as the continuity of care is concerned, you do not have to centralize in a single space and in some people the responsibility for the attention of the whole municipality. If decentralized I think the people of the Unit would feel more responsible in this flow, because today you identify the symptoms and give the collector jar for the patient to collect, and that's what you have to do, that's your commitment! (P5-P)

In fact, I think the responsibility would be entirely of Primary Health Care, the patient with tuberculosis is not only in the detection, I think that you also have to work on healing because if he does not treat it correctly or not identified quickly, it will be transmitting. But in the current reality that we are, we have managed to do very little, we were only in the realization of the requests to smear, often, without knowing the result and neither started the treatment! (P1-P) 


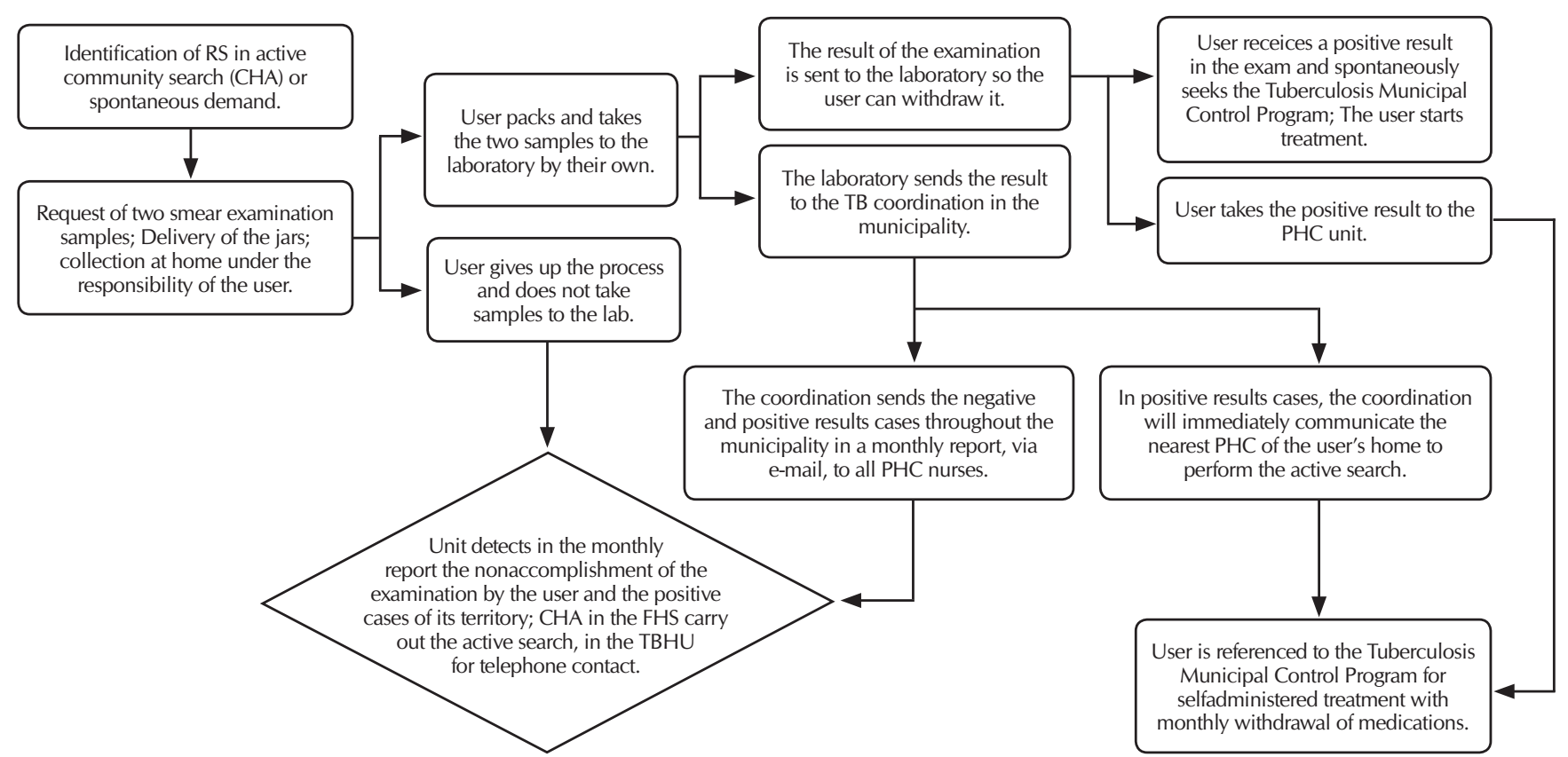

Note: RS - Tuberculosis Respiratory Symptoms; CHA - community health agents; PHC - Primary Health Care; FHS - Family Health Strategy; TBHU - Traditional Basic Units.

Figure 1 - Tuberculosis case detection flowchart in Pelotas, Rio Grande do Sul, Brazil, 2016

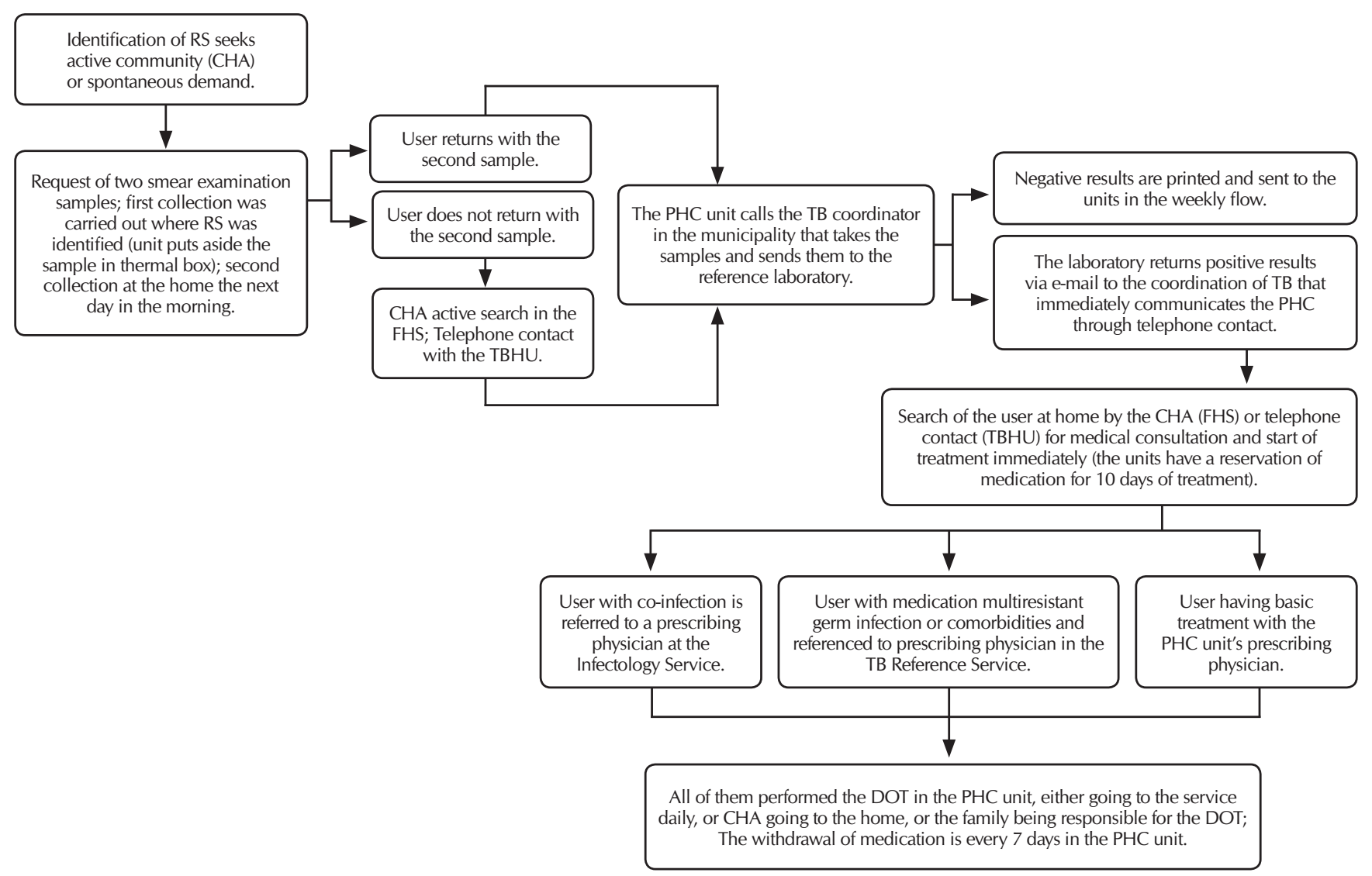

Note: RS - Tuberculosis Respiratory Symptoms; CHA - community health agents; PHC - Primary Health Care; FHS - Family Health Strategy; TBHU - Traditional Basic Units.

Figure 2 - Tuberculosis case detection flowchart in Sapucaia do Sul, Rio Grande do Sul, Brazil, 2016 
In Sapucaia do Sul, professionals believe that the flow (Figure 2 ), as it is organized, brings RS professionals closer together and strengthens the bonding process. The responsibility of the PHC ranges from suspicion to cure by directly observed treatment.

Continuity is guaranteed because it has a connection, the patient has already been listened to, already received the guidelines, in the unit, already knows that, from this examination he will be able to have the diagnosis and treatment, everything here in the territory. (P3-S)

The responsibility of Primary Health Care is very broad, I think it goes from allowing the person to have an understanding of what the sickness is, to make correct use of the medication, to follow the patient up during and until the end of treatment. My responsibility is to follow the patient up to the end of the treatment by co-responsibility. (P1-S)

This issue of decentralization I think is a potentiality of all units, have the knowledge and power to do the first service, not just the issue of referral, I think it is a potentiality of our flow of attention! (P2-S)

The reflexes of the municipal flows can be verified in the results obtained from the collection of secondary data, in the quantitative stage, for the year 2012. The quantitative of smear de sputum requests was verified, with a total of 165 records in the books of respiratory symptoms of $\mathrm{PHC}$ units in Pelotas, and 738 requests in $\mathrm{PHC}$ records from Sapucaia do Sul.

Of the 165 records of users with suspected TB of Pelotas, it was observed that $50 \%(n=84)$ arrived with the sputum sample for analysis in the municipal laboratory, of which $11.9 \%$ $(n=10)$ had a positive result (Table 1$)$. Relating this result to the number of new bacilliferous pulmonary cases diagnosed in the municipality in 2012, according to the SINAN 114 cases $^{(17)}$, it is verified that $8.8 \%(10 / 114)$ were diagnosed by PHC.

Table 1 shows the application of the estimated case indicators and the proportion of diagnoses among the SRs examined. Considering the population of Pelotas in $2012^{(16)}$ with 328,275 inhabitants, and based on the diagnostic smear records in the municipal laboratory, $40.1 \%$ of the estimated RS were identified among all municipal services, and PHC contributed with $2.6 \%$ detection of RS.

In Sapucaia do Sul, it was requested by PHC 738 smear s of sputum. Of these, $75.7 \%(n=559)$ arrived at the laboratory, being $4.3 \%(n=24)$ positive (Table 1$)$. Considering the number of new smear-positive pulmonary cases diagnosed in the municipality in the year 2012, 49 cases were reported in the SINAN ${ }^{(17)}$, according to the records of the basic health units of the municipality, 49\% (24/49) were diagnosed by PHC.

The population of Sapucaia do Sul in $2012^{(16)}$ was 130,957 inhabitants, considering the records of the municipal laboratory, the examination of 1033 smear s of sputum was performed for the diagnosis, which corresponds to $78.9 \%$ of RS estimated for the period. As can be seen in Table 1, the contribution of PHC in this indicator was $42.7 \%$.

In relation to the time between the identification in the unit (registration of request of smear in the LBRS) and the arrival of the sample in the laboratory, in Pelotas the average of 12 days was observed (ranging from 1 to 51 days). There is no record of the date of delivery of the result by the laboratory to the user or health service. From those cases diagnosed as positive, the treatment start date was identified as being 6.6 days (ranging from 0 to 14 days) between the sample entry in the laboratory and the start of treatment, the total time since the smear up to the start of treatment was on average 19 days (ranging from 3 to 57 days).

In Sapucaia do Sul, the time between the identification in the unit (smear request register) and the arrival of the sample in the laboratory is verified the average of 1.7 days, the mean of days between the sample entry in the laboratory and the release of the result was 3.3 days. From those cases diagnosed as positive, the starting date of the treatment was identified as 8.4 days (ranging from zero to 20 days) between the smear request and the beginning of treatment.

The total number of professionals interviewed in Sapucaia do Sul reported that the time between the identification of SR and the beginning of treatment varies between seven and ten days. Confirming the one identified in the quantitative step, it emphasizes the need for agility in the outcome as determinant for the beginning of the treatment.

Table 1 - Indicators of detection of tuberculosis cases in primary health care units of two priority municipalities of Rio Grande do Sul, Brazil

\begin{tabular}{|c|c|c|c|c|c|c|}
\hline Indicators for the examinations carried out in 2012 & $\underset{\mathbf{n}}{\text { Estimated }}$ & $\underset{\mathrm{n}^{*}}{\mathrm{RS}}$ & $\begin{array}{c}\text { Number of } \\
\text { diagnoses } \\
\text { by PHC } \\
n^{*}\end{array}$ & $\begin{array}{c}\text { Number of } \\
\text { diagnoses in the } \\
\text { municipality } \\
n^{\&}\end{array}$ & $\begin{array}{c}\text { All } \\
\text { services } \\
(\%)\end{array}$ & $\begin{array}{c}\text { PHC } \\
(\%)\end{array}$ \\
\hline \multicolumn{7}{|l|}{ Proportion of RS examined among the estimated } \\
\hline Pelotas & & 1316 & - & - & 40.1 & 2.6 \\
\hline Sapucaia do Sul & & 1033 & - & - & 78.9 & 42.7 \\
\hline \multicolumn{7}{|l|}{ Proportion of Diagnoses among the RS examined } \\
\hline Pelotas & & - & 10 & - & 8.7 & 11.9 \\
\hline Sapucaia do Sul & & - & 24 & - & 4.7 & 4.3 \\
\hline \multicolumn{7}{|c|}{ Proportion of diagnostics per service/diagnostics in the municipality } \\
\hline Pelotas & & - & - & 114 & 91.2 & 8.8 \\
\hline Sapucaia do Sul & & - & - & 49 & 51.0 & 49.0 \\
\hline
\end{tabular}

Note -* data collected from the municipal laboratory records book; \& data collected in the Notification of Injury Information System for the year 2012; RS - Tuberculosis Respiratory Symptoms; PHC - Primary Health Care. 
It ranges from seven to ten days. There are cases that we are very much in doubt and want to start soon, so these ten days weigh a little. If it could be less. (P1-S)

In Pelotas, the result of the examination reaches the professional, in most cases, via a monthly report, sent by the Municipal Coordinator of TB to the personal e-mail of the Nurse, which is checked at home, since not all units have computers with internet access.

Well, since the report is monthly and sometimes delays one or two months, we see the result more by the user. That patient who is very interested, and who is able to go, in a week to the laboratory, he returns quickly with the result! Now there are others who sometimes take two, three weeks, and others who do not even return, because many do not even take the exam. I discover this because I see in the e-mail of the report, when I receive! (P1-P)

I think it's from the lab that they're already referring to the treatment, and most already know that TB is in the specialty center. I never received the result of the examination in the unit by the patient. I only know about the monthly reports, but a while later. (P3-P)

Given the municipal recognition of the outpatient service, as the reference for the treatment of tuberculosis, not all users return with the result to the unit, many of them already go spontaneously to the service for the treatment. The information from the time elapsed between the request and the beginning of the treatment is not always accompanied by the PHC team, which was evidenced by the interviewees from Pelotas, as verified in the above excerpts.

\section{DISCUSSION}

The flow of case detection in the service network needs to be hired by the management and agreed with the PHC teams, so as to strengthen the organization of services to better serve the $\mathrm{RS}^{(18)}$. The determination of an organized flow, with guarantee of continuity of care, brings the users of the health service closer, strengthening the link and the resolution of the health needs presented ${ }^{(19-20)}$. In the present study, professionals from both municipalities reported that the RS flow is standardized, but there are no documents in the unit with such information, the guidance was verbally passed on to the teams by the municipal management.

The adoption of this strategy by the management in the transfer of information can cause losses related to the variation of conduct between the units, due to differences in understanding among the teams, and to encourage the lack of PHC participation in TB control ${ }^{(21)}$. This fact can be observed in the statements of P1_P and P3_P who are unaware of the way the TB user arrives until the treatment in the specialized service, as well as the lack of knowledge of the teams about the time elapsed between the request and the beginning of the treatment, evidenced in Pelotas, demonstrating the dissociation with the continuity of care and the fragmentation of TB care. This result corroborates a study carried out in the northeast of Brazil, in which the investigators verified the lack of responsibility of $\mathrm{PHC}$ teams for TB control, considering the activities related to the disease as the competence of the specialized services where treatment is given ${ }^{(4)}$.

On the other hand, in Sapucaia do Sul, where all TB control actions were decentralized to $\mathrm{PHC}$, and the existing adoption of DOT, there is evidence of a better knowledge of the professionals about the flow of RS to diagnosis, including the time elapsed from the smear request to the beginning of treatment. In this sense, it should be pointed out that decentralization is an important factor to facilitate access to health services and foster the accountability of the teams for the integral care of the individual with TB, raising the rates of case detection ${ }^{(22)}$.

In analyzing the flows of the municipalities under study, both professionals and managers reported that the community health agents $(\mathrm{CHA})$ in the FHS units performed the active community search and the TBHU passive search. Considering the low FHS coverage in 2012, in Pelotas (28.3\%) and Sapucaia do Sul $(26.2 \%)$, it is worth noting that case detection rates could be improved by increasing FHS coverage in 2016, to $70.3 \%$ in Pelotas and $49.6 \%$ in Sapucaia do Sul ${ }^{(15)}$. However, in order to achieve the recommended rates of case detection, PHC services, regardless of the care model, should promote the broad realization of the SR's active search for spontaneous service and community demand ${ }^{(23)}$.

In the flows, there are marked differences related to $\mathrm{PHC}$ participation in the case detection process between the two settings, highlighting the differences related to the collection, packaging and transportation of the smear samples to the laboratory, as well as, the receipt of information about the results of the exams and the start of treatment. These differences in the SR flow, determined from the PHC, influence the results achieved by the municipalities in the identification of RS.

Regarding the smear collection, in Sapucaia do Sul, compliance with the national guidelines ${ }^{(3,24)}$ is verified, with the packaging and transportation on PHC's responsibility. This organization favors agility in the conduct of the examination and diagnosis, since the samples being evaluated and conditioned by the $\mathrm{PHC}$ team prevent the low quality material from reaching the laboratory, necessitating a new collection. In addition to ensuring that the shipment is carried out promptly, without cost to the RS, removing from the process the interference of delay by financial situations and possible fears in the handling of the sputum by the user and his family ${ }^{(4,25)}$. This fact can be noticed when analyzing the time elapsed between the request of the examination and the beginning of the treatment, evidencing that the Sapucaia do Sul flow is agile, well below the recommended maximum delay of three weeks ${ }^{(23)}$. The Sapucaia do Sul professionals emphasize that the decentralization of control actions to PHC is a potential of the municipal organization, as it transfers responsibility for TB to PHC professionals and provides continuity of care in the territory.

In contrast, in Pelotas, the team, when identifying the RS, requests the examination, but restricts its action to the delivery of the pots and request form, together with the guidance to the user to take the samples to the municipal laboratory, which was also verified in a study carried out in Paraíba State, where PHC professionals are not responsible for the quality and delivery of 
the material to the laboratory ${ }^{(21)}$. In this setting, $\mathrm{PHC}$ professionals act as co-adjuvants in the TB detection process, as evidenced in the speech of P5_P, which reaffirms the centralization of treatment as a failure in the management of care. This result confirms the low priority given to the detection of TB cases by municipal managers, with absence of precise regulation regarding the collection flow and the sending of sputum to the laboratory ${ }^{(26)}$. This leaves PHC professionals uninstructed and unsure of their role in this process, stimulating non-accountability and overvaluation of secondary services ${ }^{(4)}$.

In fact, in Pelotas, where care coordination is not clearly defined from the request for the examination, the RS itself and its family assume, albeit informally, the role of care coordinators $^{(27)}$, being responsible for the sample collection at home, and the delivery of the examination in the laboratory, using own resources for the conservation and transportation of the same. This fragmented activity, in addition to burdening RS, resulted in delayed diagnosis, an average of 19 days, superior to that of Sapucaia do Sul, and evidenced in studies carried out in municipalities in the countryside of São Paulo ${ }^{(8,23)}$, with 15 days in mean for the diagnosis.

Another relevant aspect is the flow of information between $\mathrm{PHC}$, laboratory and management, which is related to the losses of follow-up, more pronounced in the Pelotas flow, since $50 \%$ of RS did not reach the laboratory with the sputum sample. The teams reported receiving this information in monthly reports, often with a delay of two to three months, via personal email, in which they detect the failure to perform the requested examination, and from this information they will carry out the search for RS that do not performed the examination. It is considered that there is a significant delay in the detection of potentially positive cases, which are aggravating the clinical condition and maintaining TB transmission. A similar result was identified in a study carried out in the state of Rio de Janeiro, which for the authors expresses the low priority given to the TB problem by municipal management, without investments in information systems that could expedite the diagnosis ${ }^{(26)}$. This tool is recognized as essential to expedite the detection of cases and the scope of continuity of care, since it allows the team to follow the path of RS in the service network ${ }^{(5)}$.

It was verified that the contribution of the $\mathrm{PHC}$ in the examination of the estimated RS and in the diagnostics of Sapucaia do Sul approached $50 \%$ of the total for the period studied. While in Pelotas the estimated RS was $2.6 \%$ and the contribution with diagnoses did not reach $9 \%$ of those performed in the municipality. The low PHC participation could also be observed in studies performed in Serbia ${ }^{(28)}$ and Ribeirão Preto, São Paulo ${ }^{(5)}$, where PHC contributed, respectively, with $14.1 \%$ and $15.3 \%$ of the expected diagnoses. The authors attributed to this finding the discontinuity of care, as observed in the Pelotas flow. Since, when they perceive that there is no agility in the diagnosis, the RS go in search of services that meet their health needs immediately, raising the detection rates for specialized services and Emergency Service ${ }^{(10)}$.

In relation to the proportion of positive among those examined, $\mathrm{PHC}$ of Pelotas, obtained a positive index of $11.9 \%$, while
Sapucaia do Sul was within the recommended rate of $4 \%$. The results of Pelotas, with a high proportion of positives among those examined, confirm the delay in diagnosis, and evidence that the test has been performed among individuals with strong symptoms of TB, and not as a screening tool among people with cough for more than three weeks, as recommended ${ }^{(24)}$ and ratifying the insufficiency of the established flow and the consequent maintenance of the chain of transmission.

A study carried out in the Northeast of Brazil found that $72.8 \%$ of the cases had not been diagnosed in a timely manner, which indicates the existence of failures in the detection of cases by $\mathrm{PHC}^{(10)}$. It should be pointed out that the active search strategy of RS is effective in order to diagnose bacillary pulmonary cases early, a fact that was verified in a study carried out in the Chinese province of Shandong, and Burkina Faso, Africa, in which the authors point out that the routine TB screening has improved the results achieved in detecting cases with low investment $\operatorname{costs}^{(22,29)}$.

\section{Study limitations}

The limitations of this study were related to the use of secondary data, primary health care unit book records, which presented incompleteness.

\section{Contributions to Nursing, Health or Public Policies}

The present research brings contributions to the area of Nursing and health since it discusses the detection of cases of tuberculosis, neglected disease and topic of national epidemiological relevance. The results of the study serve as subsidies for the formulation of municipal public policies to carry out the creation of care lines in order to ensure the effectiveness of reaching the goals proposed by the $\mathrm{WHO}$ for the control of $\mathrm{TB}$, through coordination actions of care. It is necessary to carry out new studies to analyze the cost effectiveness of the flows in question, in order to prove to the managers the feasibility of investments in the adoption of a comprehensive care line for TB from PHC.

\section{CONCLUSION}

In analyzing the flow of municipalities and the results achieved by them, it is concluded that the way of organizing TB-related processes, by municipal management, is decisive in promoting or limiting the commitment of the $\mathrm{PHC}$ teams in the coordination of assistance and, consequently, the goals of disease control. It is highlighted the potential of the municipal organization of Sapucaia do Sul with investments in the operationalization of case detection, in which the RS is not detached from the PHC team at any moment from the suspicion until the end of the treatment.

\section{FUNDING}

Our source of development was the National Council for Scientific and Technological Development, Notice of Neglected DIseases CNPq 4041100/2012-0. 


\section{REFERENCES}

1. World Health Organization-WHO. Global Tuberculosis Report 2016[Internet]. Genebra: WHO; 2016 [cited 2017 Jun 12 ]. Available from: http://www.who.int/tb/publications/global_report/high_tb_burdencountrylists2016-2020.pdf?ua =1

2. Brasil. Ministério da Saúde. Indicadores prioritários para o monitoramento do plano nacional pelo fim da tuberculose como problema de saúde pública no Brasil. Bol Epidemiol [Internet]. 2017[cited 2017 Jun 12];48(8):1-11. http://portalarquivos2.saude. gov.br/images/pdf/2017/marco/23/2017-V-48-N-8-Indicadores-priorit-rios-para-o-monitoramento-do-Plano-Nacional-pelo-Fim-daTuberculose-como-Problema-de-Sa--de-P--blica-no-Brasil.pdf

3. Bertolozzi MR, Takahashi RF, Hino P, Litvoc M, França FOS. O controle da tuberculose: um desafio para a saúde pública. Rev Med[Internet]. 2014 [cited 2016 Dec 12];93(2):83-9. Available from: http://www.revistas.usp.br/revistadc/article/view/97330/96342

4. Paiva RCG, Nogueira JA, Sá LD, Nóbrega RG, Trigueiro DRSG, Villa TCS. Acessibilidade ao diagnóstico de tuberculose em município do nordeste do Brasil: desafio da atenção primária à saúde. Rev Eletr Enferm[Internet]. 2014[cited 2016 Nov 20];16(3):520-6. Available from: https://www.fen.ufg.br/revista/v16/n3/pdf/v16n3a04.pdf

5. Andrade RLP, Scatolin BE, Wysocki AD, Beraldo AA, Moroe AA, Scatena LM, et al. Diagnóstico da tuberculose: atenção primária à saúde ou pronto atendimento? Rev Saúde Pública [Internet]. 2013 [cited 2016 Dec 12];47(6):1149-58. Available from: http:// www.scielo.br/pdf/rsp/v47n6/0034-8910-rsp-47-06-01149

6. Boaretto C, Bastos FI, Natal S. Os desafios para o controle da tuberculose e novas perspectivas. Cad Saúde Colet[Internet]. 2012[cited 2016 Dec 12];20(2):135-6. Available from: http://www.cadernos.iesc.ufrj.br/cadernos/images/csc/2012_2/artigos/ CSC_v20n2_135-136.pdf

7. Giovani MSP, Vieira CM. Longitudinalidade do cuidado diante da rotatividade de profissionais na Estratégia Saúde da Família. RECIIS[Internet]. 2013 [cited 2017 Jan 3];7(4). Available from: https://www.reciis.icict.fiocruz.br/index.php/reciis/article/view/572/1213

8. Ponce MAS, Wysocki AD, Arakawa T, Andrade RLP, Vendramini SHF, Silva Sobrinho RA. Atraso do diagnóstico da tuberculose em adultos em um município paulista em 2009: estudo transversal. Epidemiol Serv Saúde[Internet]. 2016[cited 2017 Jan 12];25(3):55362. Available from: http://www.scielo.br/pdf/ress/v25n3/2237-9622-ress-25-03-00553.pdf

9. Maior ML, Guerra RL, Cailleaux-Cezar M, Golub JE, Conde MB. Tempo entre o início dos sintomas e o tratamento de tuberculose pulmonar em um município com elevada incidência da doença. J Bras Pneumol[Internet]. 2012[cited 2017 Jan 20];38(2):202-9. Available from: http://www.scielo.br/pdf/jbpneu/v38n2/en_v38n2a09.pdf

10. Romero ROG, Ribeiro CMC, Sá LD, Villa TCS, Nogueira JA. Subnotificação de casos de tuberculose a partir da vigilância do óbito. Rev Eletr Enferm[Internet]. 2016 [cited 2017 Feb 1];18:e1161. Available from: https://revistas.ufg.br/fen/article/view/37249/21346

11. Brasil. Ministério da Saúde, Conselho Nacional de Saúde. Resolução n 466, de 12 de dezembro de 2012. Diretrizes e normas regulamentadoras de pesquisas envolvendo seres humanos. Diário Oficial da União[da] República Federativa do Brasil; 2013. v.13, n.150, p. 59-62.

12. Rio Grande do Sul. Secretaria Estadual de Saúde. Centro estadual de vigilância em saúde do RS. Tuberculose no Rio Grande do Sul: relatório técnico 2014-2015. Porto Alegre, 2016. Available from: http://www.saude.rs.gov.br/upload/1459169540 RELAT\%C3\%93RIO\%20TUBERCULOSE\%202016.pdf

13. Gonzales RIC. Atenção primária à saúde na detecção de casos de tuberculose em municípios prioritários do sul do Brasil: desafios e investimentos em estratégias de informação. Conselho Nacional de Desenvolvimento Científico e Tecnológico (CNPq) Chamada MCTI/CNPq/MS-SCTIE - Decit N 40/2012 - Pesquisa em Doenças Negligenciadas, 2012.

14. Minayo MCS. O desafio do conhecimento: pesquisa qualitativa em saúde. 12 ed. São Paulo: Hucitec; 2010.

15. Brasil. Ministério da Saúde. Departamento de Atenção primária à saúde. Histórico de cobertura da saúde da família. 2016[cited 2017 Feb 1]. Available from: dab.saude.gov.br/portaldab/histórico cobertura sf.php

16. Brasil. Instituto Brasileiro de Geografia e Estatística-IBGE. Cidades[Internet]. 2016[cited 2017 Feb 1]. Available from: cidades.ibge. gov.br

17. Brasil. Sistema de informação de agravos de notificação. SinanNet. Tuberculose: frequência de casos novos pulmonares com baciloscopia positiva em 2012, segundo município de residência [Internet]. 2012[cited 2017 Feb 1]. Available from: http://200.198.173.165/tabnet/

18. Wysocki AD, Ponce MAZ, Brunello MEF, Beraldo AA, Vendramini SHF, Scatena LM, et al. Atenção primária à saúde e tuberculose: avaliação dos serviços. Rev Bras Epidemiol [Internet]. 2017 [cited 2017 Jun 1];20(1):161-75. Available from: http://www.scielosp. org/pdf/rbepid/v20n1/en_1980-5497-rbepid-20-01-00161.pdf

19. Aguilera SLVU, França BHS, Moysés ST, Moysés SJ. Articulação entre os níveis de atenção dos serviços de saúde na Região Metropolitana de Curitiba: desafios para os gestores. Rev Adm Pública [Internet]. 2013 [cited 2017 Feb 1];47(4):1021-39. Available from: http://www.scielo.br/pdf/rap/v47n4/v47n4a10.pdf

20. Coelho APAC, Larocca LM, Chaves MMN, Felix JVC, Bernardinho E, Alessi SM. Gestão do cuidado da tuberculose: integrando um hospital de ensino à atenção primária à saúde. Texto Contexto Enferm [Internet]. 2016 [cited 2017 Feb 12];25(2):e0970015. Available from: http://www.scielo.br/pdf/tce/v25n2/pt_0104-0707-tce-25-02-0970015.pdf 
21. Nóbrega RG, Nogueira JA, Sá LD, Uchôa REMN, Trigueiro DRSG, Paiva RCG. Organização do serviço de controle da tuberculose em Distrito Sanitário Especial Indígena Potiguara. Rev Eletr Enferm [Internet]. 2013[cited 2017 Feb 20];15(1):88-95. Available from: https://www.fen.ufg.br/fen_revista/v15/n1/pdf/v15n1a10.pdf

22. Méda ZC, Huang C, Sombié I, Konté L, Somda PK, Djibougou AD, et al. Tuberculosis in developing countries: conditions for successful use of a decentralized approach in a rural health district. Pan Afr Med J[Internet]. 2014[cited 2017 Feb 20];17(198). Available from: https://www.ncbi.nlm.nih.gov/pmc/articles/PMC4228989/pdf/PAMJ-17-198.pdf

23. Sasaki NSGMS, Santos MLSG, Vendramini SHF, Ruffino-Netto A, Villa TCS, Chiaravalloti-Neto F. Atraso na suspeita e no diagnóstico de tuberculose e fatores relacionados. Rev Bras Epidemiol [Internet]. 2015 [cited 2017 Feb 20];18(4):809-23. Available from: http:// www.scielo.br/pdf/rbepid/v18n4/en_1980-5497-rbepid-18-04-00809.pdf

24. Brasil. Ministério da Saúde. Manual de recomendações para o controle da tuberculose no Brasil. Brasília: MS; 2011.

25. Paula R, Lefevre F, Lefevre AMC, Galesi VMN, Schoeps D. Por que os pacientes de tuberculose procuram as unidades de urgência e emergência para serem diagnosticados: um estudo de representação social. Rev Bras Epidemiol [Internet]. 2014 [cited 2017 Feb 20];17(3):600-14. Available from: http://www.scielo.br/pdf/rbepid/v17n3/1415-790X-rbepid-17-03-00600.pdf

26. Cunha NV, Cavalcanti MLT, Santos MLF, Araújo VLA, Oliveira E, Cruz DM, et al. Estrutura, organização e processos de trabalho no controle da tuberculose em municípios do estado do Rio de Janeiro, RJ, Brasil. Interface[Internet]. 2015 [cited 2017 Feb 21];19(53): 251-563. Available from: http://www.redalyc.org/articulo.oa?id=180139468003

27. Admi H, Muller E, Ungar L, Reis S, Kaffman M, Naveh N, Shadmi E. Hospital community interface: a qualitative study on patients with cancer and health care providers' experiences. Eur J Oncol Nurs [Internet]. 2013 [cited 2017 Feb 21];17:528-35. Available from: http://www.ejoncologynursing.com/article/S1462-3889(13)00025-2/pdf

28. Stošić M, Lazarević N, Kuruc V, Ristić L. Assessment of the role of primary health care in tuberculosis control in Serbia. Med Pregl [Internet]. 2015 [cited 2017 Feb 21];LXVIII(9-10):331-5. Available from: http://scindeks-clanci.ceon.rs/data/pdf/0025-8105/2015/002581051510331S.pdf

29. Zang XL, Li SG, Li HT, Li GX, Guo XY, Wang Y, et al. Integrating tuberculosis screening into annual health examinations for the rural elderly improves case detection. Int J Tuberc Lung Dis [Internet]. 2015 [cited 2017 Fev 21];19(7):787-91. Available from: https://www.ncbi.nlm.nih.gov/pubmed/26056102 